\title{
THE DEATH AND REBIRTH OF A PARTY SYSTEM, PERU 1978-2001
}

\author{
CHARLES D. KENNEY \\ University of Oklahoma
}

\begin{abstract}
This article evaluates structural, institutional, and actor-centered explanations of the collapse of the Peruvian party system around 1990 and its surprising partial recovery in 2001. It begins by describing the changes in the dependent variable, the emergence, collapse, and partial resurrection of the 1980s Peruvian party system. The next section examines the argument that the large size and rapid growth of the informal sector undermined the party system and led to its collapse. The author shows that the evidence does not support this argument. The article then examines changes in the electoral system. The author demonstrates that, contrary to theoretical expectations, the changes in the electoral system do not correlate with the observed changes in the party system. The final section shows that performance failure by political elites, including corruption in government, was more important than social cleavages or electoral institutions in the collapse and partial recovery of the party system.
\end{abstract}

Keywords: party systems, electoral systems, informal sector, Peru

66Lima is proof that there are no knowable limits to what people will put

up with" (Guillermoprieto, 1990). So wrote a visiting journalist in 1990 when inflation spiraled out of control, production plummeted, and thousands of Peruvians were being murdered in political violence that some feared was a precursor to genocide. Less noticed amid the chaos and carnage of late1980s Peru were the death throes of the party system that had dominated Peruvian politics during the previous decade. In 1990 the party system showed signs of exhaustion when Alberto Fujimori's electoral tsunami washed away the familiar political landscape. By the end of Fujimori's first term in office, not a party remained from the 1980s that was capable of seri-

AUTHOR'S NOTE: I would like to thank Michael Coppedge, Robert Cox, and two anonymous reviewers for their helpful comments. Some parts of this article analyzing the breakdown of the Peruvian party system are developed at greater length in Charles D. Kenney, Fujimori's Coup and the Breakdown of Democracy in Latin America, University of Notre Dame Press, forthcoming.

COMPARATIVE POLITICAL STUDIES, Vol. 36 No. 10, December 2003 1210-1239

DOI: $10.1177 / 0010414003258108$

(C) 2003 Sage Publications

1210 
ously contesting power. Rarely have party systems collapsed so completely and quickly.

A decade later Peruvians witnessed another amazing event, as the Fujimori regime suddenly collapsed and politicians and parties long thought dead sprang to life. The return of the 1980s politicians was even more astonishing given the thoroughness with which they had been destroyed over the previous 10 years. The so-called traditional parties that together received more than $90 \%$ of the presidential vote in the 1980s won less than $7 \%$ of the presidential vote in 1995 and less than $2 \%$ in 2000. Many were surprised, then, when candidates associated with these parties won more than $50 \%$ of the presidential first-round vote in 2001.

The unexpected collapse and the surprising partial resurrection of the 1980s parties provide an opportunity to reexamine our understanding of the forces that shape party systems. Can the dramatic changes observed in Peru best be explained by changes in the social cleavages underlying parties, by the role played by political institutions, or by the way political elites shape the party system? ${ }^{1}$ This article argues that the collapse and partial rebirth of Peru's party system was due far more to the actions of elites and the judgment of voters than to structural or institutional causes. The article begins by describing changes in the dependent variable and then examines explanations focusing on structures, institutions, and political elites.

\section{WHAT HAPPENED: THE RISE, COLLAPSE, AND PARTIAL RESURRECTION OF A PARTY SYSTEM}

The 1980s party system was born in the 1978 Constitutional Assembly and 1980 general elections that ended more than a decade of military rule. By late 1980 four political forces had emerged that dominated politics for the rest of the decade: the American Popular Revolutionary Alliance (APRA), Popular Action (AP), the Popular Christian Party (PPC), and the United Left (IU).

APRA already had a storied career stretching back five decades when it gained a plurality of the seats in the 1978 Constitutional Assembly. Overcoming the death of its founding leader in 1979, APRA emerged as a leading center-left party in the 1980s. AP was APRA's primary rival in the 1960s and 1980s, winning the presidency after military rule in 1963 and again in 1980.

1. See Mainwaring (1999, pp. 21-22) and Tanaka (1998, pp. 24-33) on structural, institutional, and elite explanations of party system change. On the collapse of the Peruvian party system, see Carrión, 1998; Cotler, 1995; Lynch, 1999; McClintock, 1994; Planas, 1996, 2000; Roberts, 1999; Tantaleán, 1996; Tuesta Soldevilla, 1995. 
Table 1

Electoral Competition in Peru, 1978-2001

\begin{tabular}{|c|c|c|c|c|c|c|c|c|c|c|c|c|c|c|c|c|}
\hline \multirow[b]{2}{*}{ Party and Alliance } & \multicolumn{2}{|c|}{$\begin{array}{c}1978 \\
\% \text { of } \\
\text { Assembly }\end{array}$} & \multicolumn{2}{|c|}{$\begin{array}{c}1980 \\
\% \text { of } \\
\text { Lower House }\end{array}$} & \multicolumn{2}{|c|}{$\begin{array}{c}1985 \\
\% \text { of } \\
\text { Lower House }\end{array}$} & \multicolumn{2}{|c|}{$\begin{array}{c}1990 \\
\% \text { of } \\
\text { Lower House }\end{array}$} & \multicolumn{2}{|c|}{$\begin{array}{l}1992 \\
\% \text { of } \\
\text { CCD }\end{array}$} & \multicolumn{2}{|c|}{$\begin{array}{c}1995 \\
\% \text { of } \\
\text { Congressional }\end{array}$} & \multicolumn{2}{|c|}{$\begin{array}{c}2000 \\
\% \text { of } \\
\text { Congressional }\end{array}$} & \multicolumn{2}{|c|}{$\begin{array}{c}2001 \\
\% \text { of } \\
\text { Congressional }\end{array}$} \\
\hline & Votes & Seats & Votes & Seats & Votes & Seats & Votes & Seats & Votes & Seats & Votes & Seats & Votes & Seats & Votes & Seats \\
\hline AP & Abst. & Abst. & 38.9 & 54.4 & 8.4 & 5.6 & - & $(14.4)^{\mathrm{a}}$ & Abst. & Abst. & 3.3 & 3.3 & 2.5 & 2.5 & 4.2 & 2.5 \\
\hline PPC & 23.8 & 25.0 & 9.6 & 5.6 & 11.1 & 6.7 & - & $(13.9)^{\mathrm{a}}$ & 9.8 & 10.0 & 3.1 & 2.5 & - & - & - & - \\
\hline Libertad & - & - & - & - & - & - & - & $(5.0)^{\mathrm{a}}$ & Abst. & Abst. & - & - & - & - & - & - \\
\hline FREDEMO & - & - & - & - & - & - & 30.1 & $34.4^{\mathrm{b}}$ & - & - & - & - & - & - & - & - \\
\hline FIM & - & - & - & - & - & - & c & 3.9 & 7.1 & 8.8 & 4.9 & 5.0 & 7.6 & 7.5 & 11.0 & 9.2 \\
\hline Renovación & - & - & - & - & - & - & - & - & 7.1 & 7.5 & 3.0 & 2.5 & - & - & - & - \\
\hline Avancemos & - & - & - & - & - & - & - & - & - & - & - & - & 3.1 & 2.5 & - & - \\
\hline Solidaridad Nacional & - & - & - & - & - & - & - & - & - & - & - & - & 4.0 & 4.2 & - & - \\
\hline Unidad Nacional & - & - & - & - & - & - & - & - & - & - & - & - & - & - & 13.8 & 14.2 \\
\hline Right & 23.8 & 25.0 & 48.5 & 60.0 & 19.5 & 12.3 & 30.1 & 38.3 & 24.0 & 26.3 & 14.3 & 13.3 & 17.2 & 16.7 & 29.0 & 25.9 \\
\hline FOCEP & 12.3 & 12.0 & 1.7 & 0.0 & - & - & - & - & - & - & - & - & - & - & - & - \\
\hline PCP/UI & 5.9 & 6.0 & 3.4 & 1.1 & - & - & - & - & - & - & - & - & - & - & - & - \\
\hline PSR + UDP & 11.2 & 10.0 & 4.3 & 1.7 & - & - & - & - & - & - & - & - & - & - & - & - \\
\hline UNIR & Abst. & Abst. & 4.7 & 1.1 & - & - & - & - & - & - & - & - & - & - & - & - \\
\hline PRT & - & - & 4.2 & 1.7 & - & - & - & - & - & - & - & - & - & - & - & - \\
\hline APS & & & 0.6 & - & - & - & - & - & - & - & - & - & - & - & - & - \\
\hline IU & - & - & - & - & 24.4 & 26.7 & 10.0 & 8.9 & Abst. & Abst. & 1.9 & 1.7 & - & - & - & - \\
\hline IS & - & - & - & - & - & - & 5.3 & 2.2 & Abst. & Abst. & - & - & - & - & - & - \\
\hline MDI & - & - & - & - & - & - & - & - & 5.5 & 5.0 & - & - & - & - & - & - \\
\hline Left & 29.4 & 28.0 & 18.9 & 5.6 & 24.4 & 26.7 & 15.3 & 11.1 & 5.5 & 5.0 & 1.9 & 1.7 & - & - & - & - \\
\hline APRA & 35.3 & 37.0 & 26.5 & 32.2 & 50.1 & 59.4 & 25.0 & 29.4 & Abst. & Abst. & 6.5 & 6.7 & 5.5 & 5 & 19.7 & 23.3 \\
\hline
\end{tabular}




\begin{tabular}{|c|c|c|c|c|c|c|c|c|c|c|c|c|c|c|c|c|}
\hline C90/NM & - & - & - & - & - & - & 16.5 & 17.8 & 49.6 & 55.0 & 52.1 & 55.8 & 42.2 & 43.3 & 4.8 & 2.5 \\
\hline UPP & - & - & - & - & - & - & - & - & - & - & 14.0 & 14.2 & 2.6 & 2.5 & 4.1 & 5.0 \\
\hline Perú Posible & - & - & - & - & - & - & - & - & - & - & 4.2 & 4.2 & 23.2 & 24.2 & 26.3 & 37.5 \\
\hline Somos Peru & - & - & - & - & - & - & - & - & - & - & - & - & 7.2 & 6.7 & 5.8 & 3.3 \\
\hline Other parties & 11.6 & 10.0 & 6.1 & 2.2 & 5.9 & 1.7 & 13.0 & 3.5 & 20.8 & 13.8 & 7 & 4.1 & 2.2 & 1.7 & 10.3 & 2.5 \\
\hline Total & 100 & 100 & 100 & 100 & 100 & 100 & 100 & 100 & 100 & 100 & 100 & 100 & 100 & 100 & 100 & 100 \\
\hline
\end{tabular}

Source: Oficina Nacional de Procesos Electorales (http://www.onpe.gob.pe); Tuesta Soldevilla, 2001.

Note: Abst. = abstained; AP = Popular Action; $\mathrm{PPC}=$ Popular Christian Party; FREDEMO = Democratic Front; FIM = Independent Moralizing Front; FOCEP = Worker Peasant Student and Popular Front; PCP = Peruvian Communist Party; UI = Unity of the Left; PSR = Revolutionary Socialist Party; UDP = Popular Democratic Unity; UNIR = Union of the Revolutionary Left; PRT = Revolutionary Party of the Workers; APS = Socialist Political Action; IS = Socialist Left; MDI = Democratic Movement of the Left; APRA = American Popular Revolutionary Alliance; C90/NM = Change 90/New Majority; UPP = Union for Peru . a. The seats in parentheses are part of the total of $34.4 \%$ of the seats belonging to FREDEMO.

b. Includes SODE's 2 seats $(1.1 \%)$.

c. Tuesta does not disaggregate FIM's vote total from the category of "others" in the 1990 elections. 
Reformist in the 1960s, AP was perceived as a party of the moderate right in the 1980s. The PPC, somewhat farther to the right, benefited from AP's boycott of the constitutional assembly to become the second-largest party there, and in 1980 it formed a governing alliance with AP. On the left, a multitude of parties vied for power separately in the 1978 Constitutional Assembly and the 1980 general elections before forming an electoral front-the IU-that held together for most of the decade. Together, these four political forces accounted for well over $90 \%$ of the legislative and presidential votes until the 1990 elections.

Although this party system never became well institutionalized, ${ }^{2}$ its collapse stunned most observers. In retrospect, we can see that the collapse took place in three stages: 1987-1989, 1989-1990, and 1992-1995. Between 1987 and 1989 the system began to show its weakness as the two leaders with the best chance of becoming president in 1990 sought alternatives to the existing parties. On the right, Mario Vargas Llosa's dissatisfaction with the existing parties led him to found the Freedom Movement (Libertad) in 1987, although he subsequently formed an electoral alliance with AP and the PPC. On the left, ideological and personal conflicts led former Lima mayor Alfonso Barrantes to break with the IU and found a new electoral alliance in 1989.

The second stage of party system collapse began in late 1989 and continued through 1990, as the traditional parties lost the municipality of Lima and the presidency while retaining a majority of the national municipal and congressional vote. The proportion of votes going to municipal candidates from other than the four traditional parties went from just less than $8 \%$ nationally in 1986 to almost $29 \%$ in 1989 . The shock to the party system was far greater in Lima, as political outsider Ricardo Belmont easily out-polled the mayoral candidates from the traditional parties.

The 1990 presidential votes went primarily to candidates who cast themselves as alternatives to the traditional parties. Vargas Llosa and Fujimori shared $62 \%$ of the first-round vote and went on to contest a runoff won handily by Fujimori. This was in sharp contrast to the previous presidential election in 1985, when citizens cast $97 \%$ of their votes for the presidential candidates of the four major parties. Although weakened, the traditional parties held their own in the legislative election of 1990, winning approximately $66 \%$ of the legislative votes (as compared to more than $94 \%$ in 1985).

As the Fujimori administration took its first steps, two contrasting views of the party system were manifested. On one hand, all of the presidential run-

2. According to two cross-national studies, Peru's party system was the least institutionalized in Latin America (Mainwaring \& Scully, 1995, pp. 4-17; Payne, Zovato, Carrillo Flórez, \& Zavala, 2002, pp. 142-143). 
Table 2

Growth of Urban Population and Informal Sector in Peru, 1940-1993

\begin{tabular}{|c|c|c|c|c|c|c|}
\hline \multirow[b]{2}{*}{ Year } & \multicolumn{4}{|c|}{$\begin{array}{l}\text { Data from the Instituto } \\
\text { Nacional de Estadística e Informática, Peru }\end{array}$} & \multicolumn{2}{|c|}{$\begin{array}{l}\text { Data from the } \\
\text { International Labour Organization } \\
\end{array}$} \\
\hline & $\begin{array}{c}\text { National } \\
\text { Urban } \\
\text { Population } \\
(\%)\end{array}$ & $\begin{array}{c}\text { National } \\
\text { Informal } \\
\text { Sector } \\
(\%)\end{array}$ & $\begin{array}{c}\text { National } \\
\text { Nonagricultural } \\
\text { Informal Sector } \\
\qquad \%)\end{array}$ & $\begin{array}{l}\text { Lima } \\
\text { Informal } \\
\text { Sector } \\
(\%)\end{array}$ & Year & $\begin{array}{c}\text { National Urban } \\
\text { Informal Sector } \\
(\%)\end{array}$ \\
\hline 1940 & 35 & 32 & 32 & 12 & - & - \\
\hline 1961 & 47 & 48 & 29 & 23 & 1960 & 47 \\
\hline 1972 & 60 & 47 & 28 & - & 1970 & 41 \\
\hline 1981 & 65 & 47 & 29 & 25 & 1980 & 41 \\
\hline 1993 & 70 & 43 & - & - & 1989 & 39 \\
\hline
\end{tabular}

Source: Instituto Nacional de Estadística e Informática, 1992 and 1993 censuses; International Labour Organization data from Portes \& Schauffler, 1996, p. 156.

off votes went to outsider candidates, which gave rise to the view that the 1980s party system had collapsed. On the other hand, traditional parties still held almost two thirds of the seats in congress, and traditional parties had played important roles in the presidential election, giving rise to the view that even though changes were evidently underway, the party system itself was largely intact.

The third stage (1992-1995) saw the collapse of the party system become complete, as traditional parties were reduced to irrelevancy in the 1995 presidential race and captured only a small number of legislative seats. Fujimori resolved his conflicts with the traditional parties in congress by means of an unconstitutional presidential coup in 1992. After international pressure forced Fujimori to hold new elections, most of the traditional parties (APRA, AP, IU) and Libertad boycotted the elections, whereas the PPC and groups that splintered from APRA, IU, and Libertad contested the elections along with several other parties.

In the municipal elections in 1993, all of the 1980s parties again participated and won $37 \%$ of the national vote. Two years later, however, these parties had all but disappeared as viable contenders for the presidency. Together, the traditional parties received less than $7 \%$ of the presidential vote and $16 \%$ of the congressional vote in 1995. By 2000 the IU and the PPC had lost their accreditation before the National Electoral Board, and the only remaining 1980s parties (APRA and AP) mustered less than $2 \%$ of the presidential and $8 \%$ of the congressional vote between them. No traditional party candidate 
had placed first or second in a presidential election since 1985, and many believed that none would again do so.

The reports of their death proved premature, however, as some of the moribund parties of the past and their leaders suddenly came alive after the dramatic collapse of the Fujimori regime in 2000. One traditional party leader (Valentín Paniagua, AP) served very successfully as interim president, and in the 2001 presidential elections two of the three major contenders in the first round were traditional party figures. The 2001 frontrunner was outsider Alejandro Toledo, who received $36.5 \%$ of the first-round presidential vote (down from 40\% in 2000), and whose Perú Posible (PP) won 26\% of the legislative vote. The PPC's Lourdes Flores Nano formed a new electoral alliance, Unidad Nacional (UN) and won $24 \%$ of the first-round presidential vote, while the UN congressional list won $14 \%$ of the votes and seats. ${ }^{3}$ Former president Alan García won $26 \%$ of the first-round presidential vote, up from APRA's $1.4 \%$ in 2000. APRA's congressional vote was also up, from $5.5 \%$ in 2000 to $20 \%$ in 2001 (and 23\% of the seats, making it the secondlargest party in the legislature). Another traditional party, AP, supported Toledo in the presidential race and won $4 \%$ of the legislative votes. Toledo went on to win the runoff, with 53\% of the vote to García's $47 \%$. Traditional party politicians ended up with just over $50 \%$ of the first-round presidential votes and at least 31 seats (26\%) in the legislature.

Having seen what happened, we can now turn to the question of why. Did changes in the structure of society provoke changes in the party system? How did the electoral system shape the party system? Were the collapse and partial recovery of the party system caused by the actions of political elites? The next sections of this article will address these questions.

3. The classification of presidential candidate Lourdes Flores Nano and the National Unity (UN) electoral alliance as traditional or nontraditional presents some difficulties. Flores Nano's party, the Popular Christian Party (PPC), lost its official status after the 1995 elections and was unable to meet the requirements for registration prior to the 2000 election, although a few PPC candidates found their way onto the lists of other parties. Flores Nano herself did not run for office in 2000, and when she ran for president in 2001, she formed a new electoral alliance that included the PPC. The analytical problem in this case is the inverse of Vargas Llosa and the Democratic Front (FREDEMO) in 1990. Vargas Llosa was a nontraditional politician, but the bulk of FREDEMO candidates elected to congress came from traditional parties (Popular Action [AP] and PPC), and it was difficult to know whether FREDEMO's votes should be counted as representing traditional or nontraditional parties. In the case of Flores Nano, she is clearly a politician associated with a traditional party, the PPC, but UN includes many politicians not associated with the 1980s parties. In this text, I count Flores Nano's presidential votes as support for a traditional politician, but I do not count the UN's legislative votes as support for the 1980s parties. 
Table 3

Legislative and Presidential Electoral and Party System Data, Peru, 1962-2001

\begin{tabular}{|c|c|c|c|c|c|c|c|c|c|c|}
\hline \multirow[b]{3}{*}{ Election } & \multicolumn{10}{|c|}{ Legislative Electoral and Party System } \\
\hline & \multirow{2}{*}{$\begin{array}{c}\text { Number } \\
\text { of } \\
\text { Chambers }\end{array}$} & \multirow{2}{*}{$\begin{array}{l}\text { Open } \\
\text { List } \\
\text { or } \\
\text { Closed } \\
\text { List } \\
\text { PR }\end{array}$} & \multirow{2}{*}{$\begin{array}{c}\text { Multiple } \\
\text { Departmental } \\
\text { or Single } \\
\text { National } \\
\text { Electoral } \\
\text { Districts }\end{array}$} & \multirow{2}{*}{$\begin{array}{l}\text { No. of } \\
\text { Legislators } \\
\text { Elected }\end{array}$} & \multirow{2}{*}{$\begin{array}{l}\text { Average } \\
\text { District } \\
\text { Magnitude }\end{array}$} & \multirow{2}{*}{$\begin{array}{c}\text { Smallest } \\
\text { Party } \\
\text { Represented } \\
(\% \text { Vote })\end{array}$} & \multicolumn{2}{|c|}{$\begin{array}{l}\text { Effective } \\
\text { Number } \\
\text { of Parties }\end{array}$} & \multirow{2}{*}{$\begin{array}{c}\text { Presidential } \\
\text { Legislative } \\
\text { Contingent } \\
(\% \text { Seats })\end{array}$} & \multirow{2}{*}{$\begin{array}{l}1980 \mathrm{~s} \\
\text { Parties } \\
\text { (\% Vote) }\end{array}$} \\
\hline & & & & & & & Votes & Seats & & \\
\hline 1963 Lower house & 2 & Closed & Multiple & 140 & 5.8 & - & - & 3.54 & 35.3 & - \\
\hline 1963 Senate & & Closed & Multiple & 45 & 1.9 & - & - & 3.25 & 44.4 & - \\
\hline 1978 Constitutional Assembly & 1 & Open & Single & 100 & 100.0 & 1.9 & 4.77 & 4.44 & - & - \\
\hline 1980 Lower house & 2 & Closed & Multiple & 180 & 7.2 & 2.6 & 4.18 & 2.47 & 54.4 & - \\
\hline 1980 Senate & & Closed & Single & 60 & 60.0 & 1.4 & 3.85 & 3.42 & 43.3 & - \\
\hline 1985 Lower house & 2 & Open & Multiple & 180 & 6.9 & 1.0 & 3.02 & 2.26 & 59.4 & 94.0 \\
\hline 1985 Senate & & Open & Single & 60 & 60.0 & 1.7 & 2.89 & 2.79 & 52.5 & 100.0 \\
\hline 1990 Lower house & 2 & Open & Multiple & 180 & 6.9 & 0.4 & 5.03 & 4.04 & 17.8 & 60.6 \\
\hline 1990 Senate & & Open & Single & 60 & 60.0 & 2.0 & 4.38 & 3.95 & 22.6 & 62.9 \\
\hline $1992 \mathrm{CCD}$ & 1 & Open & Single & 80 & 80.0 & 1.7 & 3.60 & 3.00 & 55.0 & 9.8 \\
\hline 1995 Congress & 1 & Open & Single & 120 & 120.0 & 0.8 & 3.30 & 2.91 & 55.8 & 14.8 \\
\hline 2000 Congress & 1 & Open & Single & 120 & 120.0 & 2.2 & 4.00 & 3.81 & 43.3 & 8.0 \\
\hline 2001 Congress & 1 & Open & Multiple & 120 & 4.8 & 1.4 & 6.63 & 4.37 & 37.5 & 23.9 \\
\hline
\end{tabular}




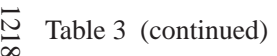

\begin{tabular}{|c|c|c|c|c|c|c|}
\hline \multirow[b]{2}{*}{ Election } & \multicolumn{6}{|c|}{ Presidential Electoral and Party System } \\
\hline & Type of Electoral System & Threshold & $\begin{array}{c}\text { Incumbent } \\
\text { Reelection } \\
\text { Allowed }\end{array}$ & $\begin{array}{l}\text { Actual No. } \\
\text { of Parties }\end{array}$ & $\begin{array}{l}\text { Effective No. } \\
\text { of Parties }\end{array}$ & $\begin{array}{c}\text { 1980s Party } \\
\text { Candidates } \\
\text { (\% Vote) }\end{array}$ \\
\hline 1962 Presidential & Top 3, congressional runoff & $33.3 \%$ valid vote & No & 7 & 3.39 & - \\
\hline 1963 Presidential & Top 3, congressional runoff & $33.3 \%$ valid vote & No & 4 & 2.98 & - \\
\hline 1980 Presidential & Top 2, congressional runoff & $36.0 \%$ valid vote & No & 15 & 3.45 & - \\
\hline 1985 Presidential & Top 2, popular runoff & $50.0 \%$ total vote & No & 9 & 2.76 & 98.4 \\
\hline 1990 Presidential & Top 2, popular runoff & $50.0 \%$ total vote & No & 9 & 3.95 & 32.3 \\
\hline 1995 Presidential & Top 2, popular runoff & $50.0 \%$ valid vote & Yes & 14 & 2.14 & 6.7 \\
\hline 2000 Presidential & Top 2, popular runoff & $50.0 \%$ valid vote & Yes & 9 & 2.42 & 1.8 \\
\hline 2001 Presidential & Top 2, popular runoff & $50.0 \%$ valid vote & No & 8 & 3.72 & 50.1 \\
\hline
\end{tabular}

Source: Oficina Nacional de Procesos Electorales (http://www.onpe.gob.pe); Tuesta Soldevilla, 2001.

Note: $\mathrm{PR}=$ proportional representation; $\mathrm{CCD}=$ democratic constitutional congress. 


\section{WHY IT HAPPENED I: SOCIAL CLEAVAGES AND THE PARTY SYSTEM}

One way to understand the emergence and transformation of party systems is to see political parties as expressions of social forces. In this view, party systems reflect a society's fundamental social cleavages, and although a party system may become "frozen," changes in the structure of society can lead to changes in the party system (Lipset \& Rokaan, 1967). Just how changes in the social structure may affect the party system is not always clear, and such effects can be difficult to disentangle from those caused by other factors.

Like most Latin American countries, Peru went from being predominantly rural to predominantly urban in the decades after World War II. Between 1940 and 1972 the proportion of Peruvians living in cities mushroomed from $35 \%$ to $60 \%$ (see Table 2). The rate of urbanization began to level off after 1970, with the urban population rising to $65 \%$ in $1981,70 \%$ in 1993, and $72 \%$ in 2000 . The transformative effects of successive waves of urban migration have been noted by many analysts of Peruvian politics and society (see, e.g., Cotler, 1995; De Soto, 1986; Franco, 1991; Grompone, 1991; López, 1991; Matos Mar, 1985; McClintock, 1999).

How do these massive changes in Peru's social structures relate to changes in the party system? Although it is reasonable to suppose that modernization and migration might have led to significant electoral realignments, it is not clear that these forces explain the collapse of the party system beginning in the late 1980s and the partial recovery of some traditional parties and politicians in 2001. The oldest Peruvian party still around today, APRA, began competing for office in 1931 when modernization and migration had advanced little in comparison to what would come after World War II. However, while Peru went through momentous changes between the 1930s and the 1970sas did APRA - the proportion of the vote going to APRA varied surprisingly little over these decades. APRA received $31 \%$ of the presidential vote in $1931,33 \%$ in $1962,34 \%$ in 1964, and 35\% of the vote for the 1978 Constitutional Assembly. Despite massive socioeconomic changes, the performance of AP founder Fernando Belaunde was also surprisingly stable, with $37 \%$ of the votes in 1956, $32 \%$ in $1962,39 \%$ in 1963 , and $45 \%$ in 1980 . The party system did see significant changes over these years, as personalist vehicles such as the Unión Revolucionaria, the Movimiento Democrático Pradista, and the Unión Nacional Odriísta came and went, but the degree of continuity is nonetheless striking.

Why, then, did party competition become so volatile in the 1980s and the party system collapse in the 1990s? In seeking to understand the collapse of 
the Peruvian party system, some authors have made special note of the rise of the so-called informal sector of the economy and its consequences for politics. According to one such view, "A major victim of the growth of the informal sector during the 1980s was the party system that had been organized around the class cleavage since the late 1970s" (Cameron, 1994, p. 17). ${ }^{4}$

I find two problems with this argument. First, the available data show that the expansion of the informal sector was not large enough or timed in such a way as to be able to explain the collapse of the Peruvian party system. Census data provided by Peru's Instituto Nacional de Estadística e Informática (INEI) give perhaps the best indication about the way the informal sector grew at the national level over the $1940-1993$ period. ${ }^{5}$ The proportion of all workers belonging to the informal sector nationwide rose rapidly between 1940 and 1961, from 32\% to 48\%, but then leveled off through 1972 and 1981 before falling to $43 \%$ by 1993 (see Table 2). Interpreting this information is not straightforward. On one hand, it appears that the growth of the informal sector from 1940 to 1960 took place only in the agricultural sector, as the nonagricultural informal sector fell between 1940 and 1960 (and continued to fall slowly through 1981). On the other hand, in metropolitan Lima the proportion of workers in the informal sector rose quickly from $12 \%$ to $23 \%$ between 1940 and 1961, only to grow slowly to $25 \%$ by 1981 .

The International Labour Organization (ILO) has estimated the size of the urban informal sector for a number of countries in Latin America since 1960. According to the ILO, the national urban informal sector in Peru fell from $47 \%$ in 1960 to $41 \%$ in 1970 and in 1980 , and then to $39 \%$ in 1989 . These data apparently reflect the same tendencies as the INEI's data on national nonagricultural informal workers. Although there is some divergence between these indices, they coincide on one point: According to all of these measures, the size of the informal sector in Peru saw little or no proportionate growth between 1960 and 1993.

This contradicts what most analysts believe is true about Peru. There are at least two possible explanations for this contradiction. First, the definition and measures of the informal sector as compiled by the INEI and the ILO may simply not be adequate for the task at hand, and their use may mask the phe-

4. In later work, Cameron and Mauceri (1997, p. 6) have continued to make the argument that "the growth of the informal sector undermined the party system and created an opportunity for anti-system candidates," and this argument has been echoed by many others (see, e.g., Schmidt, 1996, pp. 322-325).

5. Peru's censuses have not specifically inquired about informal or formal status, but the Instituto Nacional de Estadística e Informática (INEI) derives estimates based on other data collected. Whatever their limitations, the census data are the among the few data available for Peru at the national level and the only such data I have located that go back as far as 1940 . 


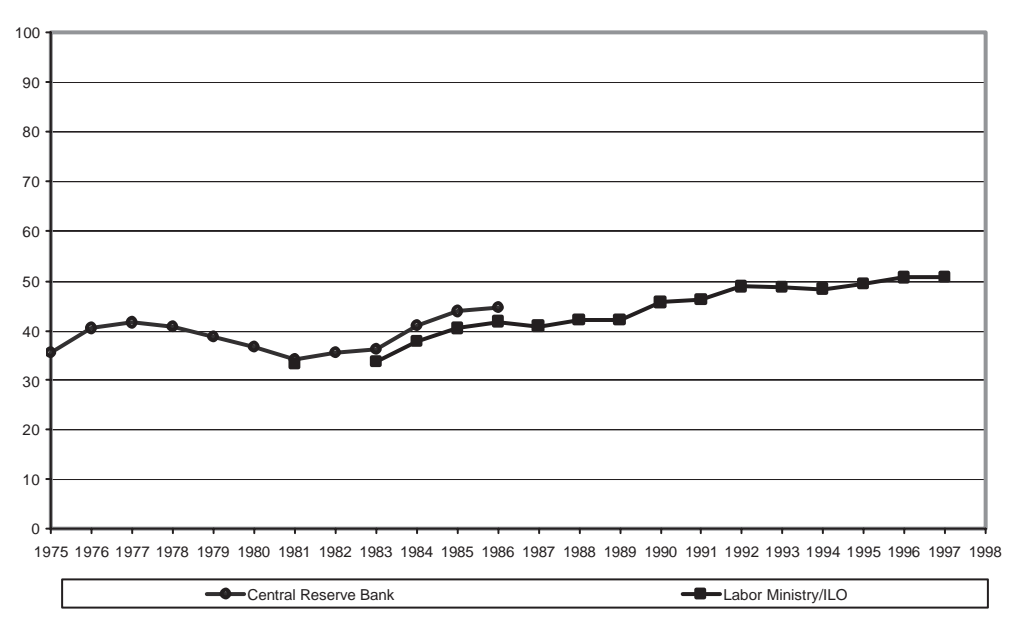

Figure 1. Evolution of Informal Sector in Metropolitan Lima, 1975-1997

Source: International Labour Organization, 2002; Instituto Nacional de Estadística e Informática, 1992.

nomena we wish to examine. It could be that the proportion of informal workers in Peru has grown significantly but that the INEI and ILO measures are the wrong ones to capture this trend. Second, it may be that analysts impressed by the growth in the absolute number of informal sector workers have not paid sufficient attention to the question of whether the proportion of informal sector workers has grown similarly. With rapid national population growth and massive rural-to-urban migration, the urban population in Peru grew from 2.2 million in 1940 to 15.5 million in 1993-an increase of over $600 \%$. The number of informal sector workers may have grown rapidly without a similar rise in the proportion of informal sector workers.

The most detailed data on the urban informal sector in Peru are limited to Lima, and these data show that the informal sector in Lima stood at 38\% when the 1980s party system was born in 1978 (see Figure 1). ${ }^{6}$ The propor-

6. The Central Reserve Bank (BCR), which reported the size of Lima's informal sector between 1975 and 1986, measured it as a percentage of the employed economically active population. The Ministry of Labor (MT), which has calculated the size of the informal sector since 1981, measured it as a percentage of the total economically active population. The two measures show identical trends, and the BCR figures reported in the text have been adjusted to follow the MT's definition. According to the MT, the informal sector includes

1 . The small property owner who produces by means of the family, who does not use salaried workers, but who nonetheless is integrated in the market selling what he or she produces. 2. Workers who work in homes with different modalities with respect to the prop- 
tion of informal sector workers reached a low of $33 \%$ in 1981 before climbing to $42 \%$ by the time the party system began to collapse. It continued to expand through the 1990 s, reaching $49 \%$ by the time the party system collapsed completely in 1995. In contrast with the national-level census datawhich show little informal sector growth after 1960 - these data indicate that the informal sector in Lima grew by as much as 11 percentage points between the birth of the party system in 1978 and its final demise in 1995.

Do these data support the argument that the rapid growth of the informal sector led to the collapse of the party system? Between the formative elections of 1978 and the 1989 elections in which the collapse of the party system in Lima first began to be noted, the informal sector rose from $38 \%$ to $42 \%$ of those employed in Lima. Although this expansion may have had electoral consequences, it remains true that the collapse of the party system began when the informal sector was only slightly larger than it had been when the party system was formed. The 1980s party system deteriorated further and collapsed completely following the 1989 municipal elections, while the informal sector continued to rise, but the two sets of changes are on different orders of magnitude. As we have seen, the traditional parties saw their share of the presidential vote drop from $98 \%$ to just $7 \%$ between 1985 and 1995 (see Table 1), while the informal sector grew from $41 \%$ to $49 \%$ of those working in Lima (see Figure 1). Perhaps the growth of the informal sector contributed to undermining support for traditional parties, but a better argument would be required to show how such massive electoral changes could be caused by relatively moderate informal sector growth, as opposed to other changes taking place at the same time.

The second problem with the argument that the growth of the informal sector led to the collapse of the party system is that most of the available data indicate that the electoral behavior of informal sector workers in Lima was not significantly different from that of lower class formal sector workers. The electoral data presented by Cameron (1994) show that the voting patterns associated with blue-collar workers are very similar to those associated with informal workers, supporting his assertion that "the informal sector is not an electoral bloc distinct from other lower-income groups" (p. 40). If this were true, even a massive expansion of the informal sector would do little to explain the demise of the party system.

erty of the means of production and production materials. 3. Independent workers and those who work in small workshops. 4. Street vendors with heterogeneous activities (INEI, 1992, p. 116, my translation). On Peru's urban informal sector, see also Balbi, 1990; Bustamante, 1990; Carbonetto, 1988; Chávez, 1990; de Soto, 1986; Kelley, 1994; Rossini \& Thomas, 1990; Thomas, 1999; Tokman, 1991; Wilson, 1998; Yamada, 1996. 
Perhaps it is not the growth of the informal sector but rather the fact that the informal sector was very large to begin with that accounts for volatility in the party system. If informal sector workers are by their nature less able to form strong bonds with parties, Peru with its large informal sector should expect to see significant electoral volatility. ${ }^{7}$ A comparison with other Latin American countries supports this argument. The correlation between mean informal sector size for 14 Latin American countries between 1960 and 1989 (ILO data reported in Portes \& Schauffler, 1996, p. 156) and mean electoral volatility between the late 1970s to 2000 (Payne et al., 2002, p. 132) is strong (Pearson's $r=.646$ ) and significant at the .05 level (two-tailed). The distinction between this argument and the argument that volatility is due to informal sector growth is underlined by the fact that the same ILO data that show a relationship between informal sector size and electoral volatility also show that the informal sector in Peru shrank between 1960 and 1989.

Explaining electoral volatility, however, is not the same as explaining party system collapse. A party system can experience significant intrasystemic volatility without collapse; what needs to be explained is not just volatility but the kind of extrasystemic volatility that destroys one party system and creates an entirely new one in its wake. In Peru, volatility between 1980 and 1985 first benefited parties within the system, and much of the legislative volatility in 1990 also benefited parties and politicians with firm roots in the 1980s system. In 1995 and 2000, on the other hand, volatility benefited parties born in the 1990s, to the complete detriment of the 1980s party system. Likewise, high electoral volatility provides a context for party system change but does little to explain why, in 2001, volatility primarily benefited parties and politicians of the 1980s. We turn next to institutional explanations of party system change.

\section{WHY IT HAPPENED II: THE ELECTORAL SYSTEM}

Electoral systems shape party systems by determining how votes are translated into legislative seats and executive positions, thereby creating incentive structures for politicians and voters (Duverger, 1954; Grofman \& Lijphart, 1986; Rae, 1967; Sartori, 1994; Taagepera \& Shugart, 1989). In what ways did Peru's electoral system and the changes made to it contribute

7. I am grateful to Steven Levitsky and an anonymous reviewer for suggesting this point. See Grompone, 1991, for a discussion of the relationship between informal sector workers and political parties. Roberts and Wibbels (1999) found no statistically significant relationship between the size of the informal sector and electoral volatility in Latin America. 
to the collapse of the party system around 1990? In what ways did the electoral system shape the recent resurgence in voting for politicians and parties associated with the 1980 s party system? We know that institutions matter, but which institutions matter in which ways, and to what extent, is a matter for investigation.

Electoral rules exert both mechanical and psychological pressures (Jones, 1995, p. 13). The mechanical effects are immediate, and some psychological effects may be as well, but when electoral rules shape party systems by shaping the expectations and incentives of politicians and voters, it may take some experience with a new set of electoral rules before behavioral changes are evident. In the Peruvian case, democratic electoral competition has been interrupted or distorted repeatedly by undemocratic actions, and the electoral system has been changed frequently within democratic bounds as well. On some occasions, politicians and voters scarcely had time to experience a new set of electoral institutions before these were undermined or changed. Consequently, this discussion focuses mostly on the more immediate effects of electoral system change.

\section{THE LEGISLATIVE ELECTORAL SYSTEM}

List proportional representation (PR) was used for the first time in the 1963 legislative elections. PR is associated with larger effective numbers of parties than are plurality elections, but the implications for the collapse of a particular party system are unclear. PR would seem to allow emerging parties greater opportunities to gain representation, but by the same token they should allow parties in decline greater possibilities of avoiding a catastrophic loss of representation. The fact that this most basic feature has remained unchanged since 1963 suggests that it is an unlikely source of the massive party system change observed in Peru since 1989.

\section{SINGLE NATIONAL ELECTORAL DISTRICTS AND MULTIPLE DEPARTMENTAL ELECTORAL DISTRICTS}

A potentially important aspect of the legislative electoral system was the use of different kinds of electoral districts. A single national district was employed for at least one legislative chamber in every election between 1978 and 2000 (see Table 3). After 1992 the multiple district system that had been used for the lower house between 1980 and 1990 (and for all legislative elections before the 1970s) was abandoned, along with bicameralism. A single national electoral district creates a highly proportional system that might be 
thought to encourage the proliferation of small parties, because even parties with very small proportions of the national vote can place candidates in the legislature. Multiple electoral districts can have two effects, however: On one hand, their smaller district magnitudes raise the effective threshold for representation in each district, which can lead to less proportional and less fragmented representation; on the other hand, multiple districts may be expected to fragment the party system by allowing regional parties to gain representation with electoral support from just one district and a very low proportion of the national vote.

After the 1993 Constitution was implemented, some argued that elections with a single national district favored Fujimori's Lima-centered electoral vehicles and hurt traditional parties with bases in the provinces. Fujimori's legislative candidates did not, however, do better in Lima than in the provinces in those elections. In 1995, Change 90/New Majority (C90/NM) received $51 \%$ of the legislative votes nationwide but just $47 \%$ in Lima. In 2000 Fujimori's party received $42 \%$ of the legislative vote both in Lima and nationwide. Traditional parties, such as APRA, AP, and IU, also did somewhat better nationwide than in Lima, but the effects were tiny in comparison to the drop in support for these parties. Neither is it clear that the single national electoral district had a strong fragmenting effect on the party system. Between 1963 and 2001, the average effective number of parties with legislative seats was 3.3 in multiple district elections and 3.4 in single national district elections. The first elections after multiple districts were abandoned (1995) saw a smaller effective number of parties than in the previous election, and the first election after multiple districts were restored (2001) saw a higher effective number of parties than in the previous election. The evidence does not support the argument that the single national electoral district had a significant negative effect on the traditional parties.

The choice between multiple districts and a single national district did have important consequences for governance. For example, Fujimori's legislative list won $52 \%$ of the vote and 56\% of the seats in 1995. As Schmidt (2000) demonstrated, if multiple districts had been employed in 1995 instead of the single national district, Fujimori's list - with the same proportion of the vote $(52 \%)$ - could have received as much as $77 \%$ of the seats. This would have given Fujimori far more than the two-thirds majority he would have needed to amend the constitution without a referendum and to control the nomination and removal of the members of such critical institutions as the Constitutional Tribunal and the Human Rights Ombudsman's Office. ${ }^{8}$ 
N్N Table 4

Comparison of Legislative Elections With Single National and Multiple Departmental Districts, Peru, 2000-200

\begin{tabular}{|c|c|c|c|c|c|c|c|c|c|c|c|c|}
\hline \multirow[b]{3}{*}{ Party } & \multicolumn{6}{|c|}{2000} & \multicolumn{6}{|c|}{2001} \\
\hline & \multicolumn{3}{|c|}{$\begin{array}{l}\text { Single District } \\
\text { (Actual) }\end{array}$} & \multicolumn{2}{|c|}{$\begin{array}{l}\text { Multiple Districts } \\
\text { (Hypothetical) }\end{array}$} & \multirow{2}{*}{ 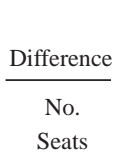 } & \multicolumn{3}{|c|}{$\begin{array}{l}\text { Multiple Districts } \\
\text { (Actual) }\end{array}$} & \multicolumn{2}{|c|}{$\begin{array}{l}\text { Single District } \\
\text { (Hypothetical) }\end{array}$} & \multirow{2}{*}{$\begin{array}{c}\text { Difference } \\
\text { No. } \\
\text { Seats }\end{array}$} \\
\hline & $\begin{array}{c}\% \\
\text { Votes }\end{array}$ & $\begin{array}{l}\text { No. } \\
\text { Seats }\end{array}$ & $\begin{array}{c}\% \\
\text { Seats }\end{array}$ & $\begin{array}{l}\text { No. } \\
\text { Seats }\end{array}$ & $\begin{array}{c}\% \\
\text { Seats }\end{array}$ & & $\begin{array}{c}\% \\
\text { Votes }\end{array}$ & $\begin{array}{l}\text { No. } \\
\text { Seats }\end{array}$ & $\begin{array}{c}\% \\
\text { Seats }\end{array}$ & $\begin{array}{l}\text { No. } \\
\text { Seats }\end{array}$ & $\begin{array}{c}\% \\
\text { Seats }\end{array}$ & \\
\hline Perú 2000/C90NM & 42.2 & 52 & 43.3 & 74 & 61.7 & -22 & 4.8 & 3 & 2.5 & 6 & 5.0 & -3 \\
\hline Perú Posible & 23.2 & 29 & 24.2 & 32 & 26.7 & -3 & 26.3 & 45 & 37.5 & 32 & 26.7 & 13 \\
\hline APRA & 5.5 & 6 & 5.0 & 2 & 1.7 & 4 & 19.7 & 28 & 23.3 & 24 & 20.0 & 4 \\
\hline Unidad Nacional & - & - & - & - & - & - & 13.8 & 17 & 14.2 & 17 & 14.2 & 0 \\
\hline Frente Independiente Moralizador & 7.6 & 9 & 7.5 & 4 & 3.3 & 5 & 11.0 & 11 & 9.2 & 13 & 10.8 & -2 \\
\hline Somos Perú/Causa Democracia & 7.2 & 8 & 6.7 & 5 & 4.2 & 3 & 5.8 & 4 & 3.3 & 7 & 5.8 & -3 \\
\hline Solidaridad Nacional & 4.0 & 5 & 4.2 & 1 & 0.8 & 4 & - & - & - & - & - & - \\
\hline Avancemos & 3.1 & 3 & 2.5 & 2 & 1.7 & 1 & - & - & - & - & - & - \\
\hline Unión por el Perú & 2.6 & 3 & 2.5 & 0 & 0.0 & 3 & 4.1 & 6 & 5.0 & 5 & 4.2 & 1 \\
\hline Acción Popular & 2.5 & 3 & 2.5 & 0 & 0.0 & 3 & 4.2 & 3 & 2.5 & 5 & 4.2 & -2 \\
\hline FREPAP & 2.2 & 2 & 1.7 & 0 & 0.0 & 2 & 1.7 & 0 & 0.0 & 2 & 1.7 & -2 \\
\hline Solución Popular & - & - & - & - & - & - & 3.6 & 1 & 0.8 & 4 & 3.3 & -3 \\
\hline Todos por la Victoria & - & - & - & - & - & - & 2.0 & 1 & 0.8 & 2 & 1.7 & -1 \\
\hline Proyecto País & - & - & - & - & - & - & 1.7 & 0 & 0.0 & 2 & 1.7 & -2 \\
\hline Renacimiento Andino & - & - & - & - & - & - & 1.4 & 1 & 0.8 & 1 & 0.8 & 0 \\
\hline Total & 100 & 120 & 100 & 120 & 100 & 0 & 100 & 120 & 100 & 120 & 100 & 0 \\
\hline
\end{tabular}

Source: Oficina Nacional de Procesos Electorales (http://www.onpe.gov.pe), author's calculations.

Note: C90NM = Change 90/New Majority; APRA = American Popular Revolutionary Alliance; FREPAP = Popular Agricultural Front of Peru 
Similarly, if the 2000 election had been run with the kind of multiple electoral districts used in 2001, Fujimori would have been elected with an outright majority in the legislature (see Table 4 ). With $42 \%$ of the valid vote distributed as it was in 2000, Fujimori would have won some 74 seats $(61.7 \%)$ under the electoral rules used in 2001 instead of the 52 seats (43.3\%) he actually won. With a comfortable majority in Congress, the outrageous buying of legislators-elect that ultimately triggered the downfall of the regime would have been unnecessary. Whether the regime would have survived is open to question, but if it fell it would have done so in a very different way than actually happened.

The switch to multiple districts in 2001, which marked the first time since 1963 that a single national electoral district had been completely abandoned, helped PP win as many as 13 additional seats in congress (see Table 4). APRA won 4 extra seats and the Union for Peru 1, whereas the change did not affect the National Unity or Andean Rebirth parties. The remaining eight parties lost between 1 and 3 seats each under the multiple district system. This has important consequences for governability, because majority coalition formation would have been much more difficult if the election had been run under the old rules.

Moreover, the changes made to the legislative electoral system in 2001 had very little to do with the partial resurgence of the 1980s parties and candidates. The party that benefited the most from the adoption of multiple electoral districts in 2001 was PP, not a 1980s party. Among the 1980s parties, APRA benefited moderately from the new arrangements with four additional seats, but AP lost two seats. In other words, the net gain due to the change in the legislative electoral system was just two seats for the 1980s parties. Although changes in the legislative electoral system have had important political consequences, they did not play a central role in the collapse of the 1980s party system or its partial recovery.

\section{THE PRESIDENTIAL ELECTORAL SYSTEM}

\section{MAJORITY RUNOFF}

The most important changes in the presidential electoral system have been the adoption of majority runoff and incumbent reelection. The first of these changes came in 1985, when Peru moved from a quasi-plurality format to a top-two majority runoff format. Under the 1933 Constitution, to become president a candidate had to win a simple plurality of the vote and gain a minimum of one third of the valid vote. If no candidate achieved one third of the 
vote, congress would choose the president from among the top three candidates. The 1980 election was run under similar rules, with the threshold for direct election set at $36 \%$. Since 1985 , presidents have been chosen according to a majority runoff system: If no candidate wins more than $50 \%$ of the votes, a runoff election is held between the top two first-round finishers.

Theory suggests that the introduction of a majority runoff system will increase the number of candidates competing and result in a more fragmented party system, as measured by the effective number of parties. ${ }^{9}$ Because the threshold for success in the first round of the election is simply to finish second, politicians will feel less compelled to form electoral alliances or to avoid splitting from their parties, leading to competition by a larger number of parties. From the point of view of voters, casting a "sincere" vote for one's first preference becomes less costly, because the second-round vote can be used strategically to block the election of an undesired candidate. One might expect, then, that the move to majority runoff would be accompanied by an increase in the absolute number of parties and in the effective number of parties competing for the presidency.

In Peru, this did not occur. ${ }^{10}$ Under the quasi-plurality system in effect before 1985 the number of presidential candidates had already mushroomed to 15 in 1980, before significant changes were made in the presidential electoral system (see Table 3 ). When majority runoff was implemented in 1985,

9. See Jones, 1995; Shugart and Carey, 1992; and Wright and Riker, 1989.

10. Thus, accounts such as Shugart and Carey (1992) present in Presidents and Assemblies need to be corrected. They wrote

Peru is an example of a party system in which the use of majority runoff for presidential elections may be blamed for a proliferation of candidates. What had been a two-bloc party system before military intervention in 1968 led to two consecutive presidential elections in the 1980 s that were won by first-round majorities of valid votes cast. However, by 1990 the majority runoff rules encouraged two "outsiders" to enter the first round as challengers to the established party system. With a decisive plurality election, such proliferation would have been far less likely. (pp. 214-215)

(See also Cameron, 1994, p. 112, and Jones, 1995, p.101.) This paragraph contains three significant errors that may have shaped Shugart and Carey's overall evaluation of majority runoff in Peru. In the first place, the party system before the 1968 military coup was a three-bloc, not a twobloc, system with an effective number of presidential parties of 2.98 and an effective number of legislative parties of 3.54. Second, the implementation of majority runoff in 1985 was preceded by a proliferation of candidates in 1980 . Third, the 1980 election was not won by a first-round majority of the valid votes cast but by a simple plurality of $45 \%$. Neither is it true, as claimed by McClintock (1994,p. 289), that "the number of parties competing for the presidency was greater after the introduction of the second-round procedure than before.' In Peru, as can be seen in Table 3 , the implementation of presidential majority runoff brought neither a proliferation of presidential candidates, nor an increase in the effective number of presidential parties, nor a drop in the size of presidential contingents in the legislature. 
the absolute number of parties fell in 1985 and 1990. It rose again in 1995 but dropped to previous levels in 2000 and 2001. The effective number of presidential parties also failed to follow the predicted pattern. Before the introduction of majority runoff, the effective number of presidential parties went from 3.39 in 1962 to 2.98 in 1963 and to 3.45 in 1980. Instead of rising when majority runoff was implemented in 1985, the effective number of parties fell to 2.76. It rose again in 1990 but fell back in 1995 and 2000. In 2001, it rose to a level of 3.72. The average effective number of presidential parties during the period of quasi-plurality elections was actually somewhat higher (3.27) than under majority runoff (3.00). In Peru, the adoption of majority runoff has not been associated with greater party system fragmentation.

What, then, were the political consequences of the adoption of presidential majority runoff? Schmidt (1996, p. 321) argues that one of the most important electoral rules that led to Fujimori's 1990 upset victory was presidential majority runoff. Majority runoff, says Schmidt, "allowed Fujimori to build support in two stages" (p. 348), and some might draw the conclusion that majority runoff is especially advantageous for political outsiders (Jones, 1995, pp. 96-97). In Fujimori's case this seems plausible, but we should be cautious before concluding that presidential majority runoff contributed significantly to the collapse of the 1980s party system or that it leads to the election of outsider candidates generally.

Although it is true that majority runoff allows initially weak candidates to build support in two stages, this does not entail majority runoff promoting the election of political outsiders in most cases. Consider two kinds of situations: one, when the top two first-round finishers are both party system insiders (as was the case with García and Barrantes in 1985); the other, when they are both outsiders (as was the case with Vargas Llosa and Fujimori in 1990, Fujimori and Pérez de Cuellar in 1995, and Fujimori and Toledo in 2000). ${ }^{11}$ In both types of cases, the net benefit to outsiders is zero.

Even when a runoff pits an insider against an outsider, this will not necessarily be to the advantage of the outsider. If the outsider happens to be the front-runner in the first round (as would have been the case if Vargas Llosa had faced APRA's Alva Castro in the 1990 runoff, or as was the case when Alejandro Toledo faced APRA's Alan García in the 2001 runoff), the outsider's first-round lead is put in jeopardy. For the two-round format to work to the advantage of an outsider, it is necessary for the outsider to be the firstround runner-up to an insider front-runner. Even then, whether the runoff

11. I define as an outsider a politician who has become politically prominent from outside of the national party system; political insiders are those who rise to political prominence from within the party system, including those who subsequently break with their old parties to form new ones (Kenney, 1998). 
favors an outsider depends on the outsider and insider's locations with respect to the distribution of voter preferences. In the simplest case of a single-issue dimension with a normal distribution of voters, a two-round format will most likely benefit the runoff candidate closest to the median voter. If the runoff pits an insider centrist politician against an outsider who occupies an ideologically extreme position, the runoff system actually makes it harder for the outsider to come to power than would a simple plurality system.

Thus, although it is true that the majority runoff format favored Fujimori in 1990, this was not a property of the electoral system itself but was highly dependent on the positions of Fujimori and Vargas Llosa in relation to the median voter. According to data from an April 1990 Apoyo poll, Fujimori's Change ' 90 party was seen by voters as a centrist party (with a mean ideological location of 5.3 on a 10-point scale), whereas Vargas Llosa's Democratic Front (FREDEMO) alliance was seen as far to the right (with a mean ideological location of 8.3). The advantage that accrued to Fujimori in 1990 had everything to do with the fact that he was able to garner the support of most voters in the center and to the left of the ideological spectrum, whereas Vargas Llosa's principal support was limited to the right. Outsiders such as Lima's Ricardo Belmont and Venezuela's Hugo Chávez have easily won election under plurality formats and would not necessarily be advantaged by majority runoff formats.

\section{PRESIDENTIAL REELECTION}

The other major change in the presidential electoral system was allowing immediate presidential reelection in 1995 and 2000, and its renewed prohibition in 2001. The presence of an incumbent running for reelection tends to reduce party system fragmentation (Jones 1999), and the evidence from Peru fits this pattern well. The average effective number of presidential parties was 3.38 while reelection was prohibited but just 2.28 for the two elections in which Fujimori ran for reelection.

Did the introduction of presidential reelection in 1995 contribute to the collapse of the 1980s party system? To the extent that reelection strengthened Fujimori, the greatest adversary of the 1980 s party system, it may be said to have played a role. Had Fujimori not run for reelection, it is possible that the 1980s parties - which still received 37\% of the municipal vote in 1993could have enjoyed a partial recovery. However, two things should also be kept in mind. First, the collapse of the party system began long before presidential reelection was adopted, so the role of reelection in the collapse is limited to the final demise of the party system in 1995. Second, the leading opposition figures to Fujimori after the adoption of presidential reelection were 
not representatives of one of the 1980s parties, but party system outsiders. Although presidential reelection may have hurt the 1980s parties in 1995 and 2000 , the primary beneficiaries of a continued prohibition on presidential reelection might well have been other outsider candidates rather than the 1980s parties.

Did the renewed prohibition of presidential reelection contribute to the partial resurgence of traditional party candidates in 2001? Once Fujimori fled the country, the question of presidential reelection became moot for the 2001 election. The primary beneficiary of Fujimori's fall was another outsider, Alejandro Toledo, not a candidate associated with the 1980s parties.

Institutions matter, but exactly how institutions such as electoral systems affect party systems requires careful analysis. Although Peru's electoral system has had an important role in shaping some specific aspects of the party system, the overall relationship between electoral system change and the most important changes in the party system is weak. In particular, electoral system variables do little to explain the massive collapse of the 1980s party system in the early 1990s and its partial recovery in 2001.

\section{WHY IT HAPPENED III: PERFORMANCE FAILURE AND THE ROLE OF POLITICAL ELITES}

Those who bear the greatest responsibility for the collapse of the party system in Peru were those who successfully captured the political center, and with it the presidency. Presidents Belaunde and García failed utterly to resolve the dramatic economic and security crises Peru confronted in the 1980s. During the 5 years Belaunde was in office, per capita GDP fell by $11 \%$ and inflation accumulated to $3,584 \%$. Belaunde also saw the eruption of a dirty war that cost over 8,000 lives during his administration and made Peru known as a land of torture and mass graves. Given his doleful performance in government, it is unsurprising that Belaunde's approval rating fell from $75 \%$ in 1980 to just $26 \%$ by 1985 , and that the public desisted from entrusting national government to Belaunde's AP party.

Belaunde's failure contributed to García's initial success. Where Belaunde seemed feeble and out of touch, García represented vigor and a welcome popular touch. Under García the economy first appeared to improve and the deaths from political violence slowed, but by 1990 the hopes raised at the beginning of García's administration had been cruelly crushed. During García's administration, per capita GDP fell a total of $15 \%$, and by his last year in office annual inflation had skyrocketed to more than $3,800 \%$. Accu- 
mulated inflation during García's 5 years was more than 600 times that experienced under Belaunde. The number of dead continued to mount (more than 10,000 during García's administration), and the number of subversive attacks grew (from 1,760 per year in 1984 to 3,149 per year in 1989). Moreover, by the end of García's government the Shining Path appeared to be making qualitative advances in its war against the Peruvian state, and many despaired of ever defeating the group. García's popularity fell even further than Belaunde's (from $90 \%$ to $21 \%$, having reached a low of $9 \%$ in 1989), and the only surprising thing about the 1990 elections is that García's APRA party did not do worse. After both administrations, the electorate punished the incumbents by taking its votes elsewhere: AP's presidential vote dropped 38 percentage points between 1980 and 1985, and APRA's presidential vote fell 31 points between 1985 and 1990.

Public rejection of AP and APRA is easy to understand and was the greatest source of electoral volatility in 1985 and 1990. To understand the full collapse of the 1980s party system, we also need to ask why voters also turned away from the other two important parties of the 1980s party system, IU and the PPC. Two factors were primarily responsible for the PPC's chronic electoral weakness. ${ }^{12}$ First, the PPC was perceived as extremely conservative. In June 1987, Apoyo poll respondents gave the PPC an average score of 8.3 on a 10-point left-right scale on which the average respondent was located at 5.4. None of the principal parties were located farther (2.9 points) from the average voter in 1987 than the PPC. Second, the PPC was perceived as socially exclusive. The vast majority of those who supported the PPC in Lima (73\%, according to a November 1986 Apoyo poll) came from the tiny upper and small middle classes. The PPC appealed to fewer still in the rest of the country. In 1985, when the PPC made its strongest ever showing in a presidential election, its candidate won $19 \%$ of the vote in Lima but averaged less than $8 \%$ in the departments and provinces outside of Lima. Even at the end of García's catastrophic administration in 1990, APRA's presidential candidate received almost twice the share of the national vote $(23 \%)$ won by the PPC's best presidential candidate (12\% in 1985).

The challenge for the various parties of the left in Peru was twofold: to unite and remain united, and to find a way to appeal ideologically to a majority of voters. The left in Peru was only partially successful on both counts. After they failed to unite for the 1980 general elections, parties of the moderate and radical left were brought together in an electoral front called the IU. Between its debut in the 1980 municipal elections and its rupture in 1989, the

12. Although the PPC might be thought to have suffered electorally because of its shared responsibility for the failures of the 1980-85 AP-PPC coalition government, in fact, the PPC saw its legislative and presidential vote increase slightly between 1980 and 1985. 
IU received on average twice as many votes as the PPC (between 23\% and $31 \%$ of the national vote), winning the mayoralty in Lima in 1983, placing second in the 1985 presidential election, and running first for many months in the polls leading up to the 1990 presidential elections. Despite the support given it by as much as a third of the electorate, the IU never became an organized political party; it remained an electoral front of fractious parties and independents led first by Alfonso Barrantes and later by a collegial leadership. It was divided not only by ideology and personal ambitions but also by different bases of support, and a growing number of IU activists were not members of any of its constituent parties but were independent members of the electoral front.

The tensions between the more moderate and radical wings of the IU were exacerbated by the worsening economic crisis, the emergence of the Shining Path and Túpac Amaru insurgencies, Barrantes's support of the García presidency, and Barrantes's own ambivalence as a candidate. When IU attempted to become more than just an electoral front and organize itself as a membership party in late 1988 and early 1989, these long-standing ideological and personal differences came to the fore and led to its division into two electoral alliances. One alliance retained the name of United Left, whereas the other was known first as the Socialist Accord of the Left and then as the Socialist Left (IS).

The public bickering surrounding IU's schism and the fact of the schism itself led the left to lose credibility as a force capable of governing the country. Looking and sounding like a dysfunctional family undergoing a particularly messy divorce, the factions that had once constituted the IU became the disunited left and thereby convinced most of the public that might have considered voting for them that neither organization was prepared to govern the country at this critical juncture, and that a vote for either would be wasted. ${ }^{13}$

Although the left's downward trajectory was primarily a product of domestic politics, it may have been furthered by the ideological dislocation that followed the fall of the Berlin Wall in November 1989. By 1990 both of the leftist alliances were perceived by voters to be farther to the left than the IU had been in 1987 (see Apoyo polls, June 1987 and April 1990). In this way the left removed itself as a serious alternative to the failed centrist parties, AP and APRA. Coupled with the limitations of the PPC, the Peruvian party system had exhausted itself. Every major party or alliance had made itself unelectable, either by demonstrating incompetence and corruption while in

13. In his study of vote switching in the 1990 election, Dietz (1998) found that "those who switched from the left to another party often mentioned the splits within the left and equated a vote for the left with a throwaway vote" (p. 219). 
government (AP and APRA), by failing to become more ideologically moderate and socially inclusive (PPC), or by dividing prior to the elections while remaining ideologically distant from the average voter (the left). Neither the rise of the informal sector nor changes in the electoral system played as central a role in the collapse of the Peruvian party system as the parties and their leaders themselves.

\section{PERFORMANCE FAILURE AND ANTIPARTY SUCCESS}

Into this political vacuum stepped Fujimori, with the support-at first clandestine-of President García. ${ }^{14}$ Fujimori appeared out of nowhere, positioned himself in the center, and became the candidate of a majority of voters. If Fujimori was initially the product of the collapse of support for the 1980s parties, once in office he did much to undermine public support for parties, and the final collapse of the party system came only as a consequence of his success as an antiparty president. From his election in 1990 until his fall from power in 2000, Fujimori epitomized the antiparty politician, attacking parties as the source of all evil in politics. Fujimori's antiparty discourse, coupled with the very real corruption and incompetence of the 1980s parties and Fujimori's own success in stabilizing the economy, creating conditions for macroeconomic growth, and defeating the Shining Path insurgency, corroded most of what support remained for the 1980s parties after 1990. Annual inflation had dropped to $10 \%$ by 1995 , and GDP grew by $4.8 \%$ in $1993,12.8 \%$ in 1994, and $8.6 \%$ in 1995 . After the arrest of many Shining Path leaders in 1992, the number of those killed in political violence fell dramatically, from 3,101 in 1992 to 652 in 1994 according to Interior Ministry figures.

Fujimori's actions also divided the already weakened parties, setting the stage for their complete collapse. His lack of a majority in the legislature contributed to the decision to close congress and suspend the constitution in 1992. International pressure led to new elections later that year, but the parties split over whether to participate, further undermining the 1980s party system. The 1995 elections marked the final collapse of the old party system, a collapse confirmed in the 2000 elections.

14. See Schmidt (1996) for an account of Alan García's clandestine support of Fujimori prior to the first round of the presidential elections in April 1990. 


\section{RESURRECTION?}

Two kinds of resurrections took place in 2001. On one hand, well-known politicians associated with the 1980s party system made a comeback. These included Alan García (APRA), Lourdes Flores Nano (PPC, UN), and Javier Diez Canseco (IU, Union for Peru), none of whom had run for office in 2000. Flores Nano and Diez Canseco returned to prominence through new (UN) or different (Union for Peru) electoral vehicles, while Alan García led his APRA party to its best showing since he was elected president in 1985. This signaled the second resurrection, not just of traditional politicians but of a traditional party. Over half of the first-round presidential vote went to candidates associated with the 1980s parties (García and Flores Nano), and almost half of the runoff vote went to García. Two of the traditional parties-APRA and AP, Peru's oldest parties-won close to a quarter of the legislative votes and seats. Members of the PPC were also among the $17 \mathrm{UN}$ candidates who won seats.

Neither the fall of Fujimori nor the partial recovery of the 1980s parties and politicians can be easily explained by structural or institutional factors. The informal sector continued to grow slowly in the late 1990s, but there is nothing in this pattern of growth that would explain Fujimori's downfall. Nor did changes in the electoral system lead to the partial recovery of the 1980s politicians and parties.

Despite a drop in approval from 77\% in August 1995 to 23\% in July 1997 and poor economic performance in 1998 and 1999, Fujimori's approval ratings rose from 33\% in December 1998 to 53\% in December 1999, according to Apoyo. Even the many scandals surrounding the 2000 elections did not seriously erode Fujimori's approval levels, which remained above $50 \%$ between December 1999 and June 2000. It was not until the 14 September 2000 broadcast of a video showing presidential adviser Vladimiro Montesinos bribing a legislator-elect to switch parties that the problem of corruption within the regime undercut popular support for Fujimori. In October his approval rating dropped to $36 \%$ and in November, just before his flight to Japan, faxed resignation, and removal by congress, it dropped to $24 \%$.

Corruption explains much of the collapse of the Fujimori regime, but it does not explain the resurgence of the 1980s politicians and parties in 2001. It stands to reason that opposition figures would be rewarded after many of their allegations against the Fujimori administration were shown to be true. Many of the leading opposition figures were themselves outsiders, however, or at least sought to present themselves as disconnected from the 1980s parties. It was not at all evident in 2000 that politicians associated with the 1980s parties would benefit so strongly in the wake of Fujimori's fall, and it was 
especially surprising that APRA's García, whose name had been made synonymous with government incompetence and corruption, would do so well.

Further research will be necessary to properly account for the unexpected 2001 resurgence of traditional parties and politicians, but it is enough for our present purposes to note that it is unlikely that changes in social cleavages or the electoral system played a major role. The partial rebirth of the 1980s party system, like its earlier demise, seems to have been due far more to actions of elites and the reactions of the public than to structural or institutional causes.

\section{REFERENCES}

Balbi, Carmen Rosa, \& Gamero, Julio. (1990). Los trabajadores en los 80: Entre la formalidad y la informalidad [Workers in the '80s: Between formality and informality]. In Movimientos sociales: Elementos para una relectura (pp. 55-109). Lima, Peru: Centro de Estudios y Promoción del Desarrollo.

Bustamante, Alberto. (1990). Informalidad: Superando las viejas tesis [Informality: Overcoming the old theses]. In De marginales a informales (pp. 15-32). Lima, Peru: Centro de Estudios y Promoción del Desarrollo.

Cameron, Maxwell. (1994). Democracy and authoritarianism in Peru: Political coalitions and social change. New York: St. Martin's.

Cameron, Maxwell. (1997). Political and economic origins of regime change in Peru: The eighteenth brumaire of Alberto Fujimori. In Maxwell A. Cameron \& Philip Mauceri (Eds.), The Peruvian labyrinth: Polity, society, economy (pp. 37-69). University Park: Pennsylvania State University Press.

Cameron, Maxwell, \& Mauceri, Philip. (1997). Introduction. In Maxwell A. Cameron \& Philip Mauceri (Eds.), The Peruvian labyrinth: Polity, society, economy (pp. 1-9). University Park: Pennsylvania State University Press.

Carbonetto, Daniel, Hoyle, Jenny, \& Tueros, Mario. (1988). Lima: Sector informal [Lima: Informal sector]. Lima, Peru: Centro de Estudios para el Desarrollo y la Participación.

Carrión, Julio. (1998). Partisan decline and presidential popularity: The politics and economics of representation in Peru. In Kurt Von Mettenheim \& James Malloy (Eds.), Deepening democracy in Latin America (pp. 55-70). Pittsburgh, PA: University of Pittsburgh Press.

Chávez, Eliana. (1990). El empleo en los sectores populares urbanos: De marginales a informales [Employment in the popular urban sectors: From marginal to informal]. In $D e$ Marginales a Informales (pp. 71-124). Lima, Peru: Centro de Estudios y Promocion del Desarrollo.

Cotler, Julio. (1995). Crisis política, “outsiders" y democraduras: El "Fujimorismo" [Political crisis, outsiders, and democraduras: Fujimorism]. In Carina Perelli, Sonia Picado, \& Daniel Zovatto (Eds.), Partidos y clase política en América Latina en los 90 (pp. 117-142). San José, Costa Rica: Instituto Interamericano de Derechos Humanos.

de Soto, Hernando, Ghersi, Enrique, \& Ghibellini, Mario. (1986). El otro sendero: La revolución informal [The other path: The informal revolution]. Lima, Peru: El Barranco.

Dietz, Henry. (1998). Urban poverty, political participation, and the state: Lima 1970-1990. Pittsburgh, PA: University of Pittsburgh Press.

Duverger, Maurice. (1954). Political parties. London: Methuen. 
Franco, Carlos. (1991). Exploraciones en "otra modernidad": De la migración a la plebe urbana [Exploration in the "other modernity": From migration to the urban plebe]. In Henrique Urbano (Ed.), Modernidad en los Andes (pp. 189-212). Cusco, Peru: Centro de Estudios Regionales Andinos "Bartolomé de las Casas."

Grofman, Bernard, \& Lijphart, Arend (Eds.). (1986). Electoral laws and their political consequences. New York: Agathon.

Grompone, Romeo. (1991). El velero en el viento: política y sociedad en Lima [Sailboat in the wind: Politics and society in Lima]. Lima, Peru: Instituto de Estudios Peruanos.

Guillermoprieto, Alma. (1990, October 29). Letter from Lima. The New Yorker, 66, 116-129.

Instituto Nacional de Estadística e Informática. (1992). Perú: Estadísticas del sector informal [Peru: Informal sector statistics]. Lima, Peru: Author.

International Labour Organization. (2002). STAT Working Paper No. 1-2002: ILO compendium of official statistics on employment in the informal sector. Geneva, Switzerland: Author.

Jones, Mark. (1995). Electoral laws and the survival of presidential democracies. Notre Dame, IN: University of Notre Dame Press.

Jones, Mark P. (1999). Electoral laws and the effective number of candidates in presidential elections. Journal of Politics, 61(1), 171-184.

Kelley, Bruce. (1994). The informal sector and the macroeconomy: A computable general equilibrium approach for Peru. World Development, 22(9), 1393-1411.

Kenney, Charles. (1998). Outsider and anti-party politicians in power: New conceptual strategies and empirical evidence from Peru. Party Politics, 4(1), 57-75.

Lipset, Seymour Martin, \& Rokkan, Stein. (1967). Cleavage structures, party systems, and voter alignments: An introduction. In Seymour Martin Lipset \& Sein Rokkan (Eds.), Party systems and voter alignments: Cross national perspectives (pp. 1-64). New York: Free Press.

López, Sinesio. (1991). El dios mortal: Estado, sociedad y politíca en el Perú del siglo XX [The mortal god: State, society, and politics in Peru in the 20th century]. Lima, Peru: IDS.

Lynch, Nicolas. (1999). Una tragedia sin héroes: La derrota de los partidos y el origen de los independientes, Perú 1980-1992 [A tragedy without heroes: The defeat of the parties and the origin of the independents, Peru 1980-1992]. Lima, Peru: Fondo editorial de la Universidad de San Marcos.

Mainwaring, Scott. (1999). Rethinking party systems in the third wave of democratization: The case of Brazil. Stanford, CA: Stanford University Press.

Mainwaring, Scott, \& Scully, Timothy. (1995). Introduction: party systems in Latin America. In Scott Mainwaring \& Tim Scully (Eds.), Building democratic institutions: Parties and party systems in Latin America, (pp. 1-34). Stanford, CA: Stanford University Press.

Matos Mar, J. (1985). Desborde popular y crisis del estado [Popular overflow and state crisis]. Lima, Peru: Instituto de Estudios Peruanos.

McClintock, Cynthia. (1999). Peru: Precarious regimes, authoritarian and democratic. In Larry Diamond, Jonathan Hartlyn, Juan Linz, \& Seymour Martin Lipset (Eds.), Democracy in developing countries: Latin America (2nd ed., pp. 309-365). Boulder, CO: Lynne Rienner.

McClintock, Cynthia. (1994). Presidents, messiahs, and constitutional breakdowns in Peru. In Juan J. Linz \& Arturo Valenzuela (Eds.), The failure of presidential democracy: The case of Latin America (pp. 286-321). Baltimore: Johns Hopkins University Press.

Payne, J. Mark, Zovatto, Daniel, Carillo Flóres, Fernando, \& Allamand Zavala, Andrés (Eds.). (2002). Democracies in development politics and reform in Latin America. Washington, DC: Inter-American Development Bank \& International Institute of Democracy and Electoral Assistance. 
Planas, Pedro. (1996). ¿Existe un sistema de partidos en el Perú? [Does a party system exist in Peru?]. In Fernando Tuesta Soldevilla (Ed.), Los enigmas del poder: Fujimori 1990-1996 (pp. 169-201). Lima, Peru: Fundación Friedrich Ebert.

Planas, Pedro. (2000). La democracia volátil: Movimientos, partidos, líderes políticos y conductas electorales en el Perú contemporáneo [Volatile democracy: Political movements, parties, leaders and electoral behavior in contemporary Peru]. Lima, Peru: Friedrich Ebert Stiftung.

Portes, Alejandro, \& Schauffler, Richard. (1996). Competing perspectives on the Latin American informal sector. In Satya R. Pattnayak (Ed.), Globalization, urbanization, and the state: Selected studies on contemporary Latin America (pp. 145-177). London: University Press of America.

Rae, Douglas. (1971). The political consequences of electoral laws (Rev. ed.). New Haven, CT: Yale University Press.

Roberts, Kenneth. (1999). Deepening democracy? The modern left and social movements in Chile and Peru. Stanford, CA: Stanford University Press.

Roberts, Kenneth, \& Wibbels, Erik (1999). Party systems and electoral volatility in Latin America: A test of economic, institutional, and structural explanations. American Political Science Review, 93(3): 575-590.

Rossini, R. G., \& Thomas, J. J. (1990). The size of the informal sector in Peru: A critical comment on Hernando de Soto's El otro sendero. World Development, 18(1), 125-135.

Sartori, Giovanni. (1994). Comparative constitutional engineering: An inquiry into structures, incentives, and outcomes. New York: New York University Press.

Schmidt, Gregory. (2000). Accounting for unexpected preferences in electoral design: The distrito unico and preferential voting in Peru. Miami, FL: Latin American Studies Association.

Schmidt, Gregory. (1996). Fujimori's 1990 upset victory in Peru: Electoral rules, contingencies, and adaptive strategies. Comparative Politics, 28(3), 321-354.

Shugart, Matthew Soberg, \& Carey, John M. (1992). Presidents and assemblies: Constitutional design and electoral dynamics. Cambridge, UK: Cambridge University Press.

Taagepera, Rein, \& Shugart, Matthew Soberg. (1989). Seats and votes: The effects and determinants of electoral systems. New Haven, CT: Yale University Press.

Tanaka, Martín. (1998). Los espejismos de la democracia: El colapso del sistema de partidos en el Perú, 1980-1995, en perspectiva comparada [The mirages of democracy: The collapse of the party system in Peru, 1980-1995, in comparative perspective]. Lima, Peru: Instituto de Estudios Peruanos.

Tantaleán Arbulú, Javier. (1996). ¿Liquidación de los partidos? Ideología neoliberal y ciclos políticos en la historia [Liquidation of the parties? Neoliberal ideology and political cycles in history]. Socialismo y Participación, 73, 81-94.

Thomas, Jim. (1999). El mercado laboral y el empleo [The labor market and employment]. In John Crabtree \& Jim Thomas (Eds.), El Perú de Fujimori (pp. 255-296). Lima, Peru: Universidad del Pacifíco, IEP.

Tokman, Victor. (1991). El sector informal: Quince años después [The informal sector: Fifteen years later]. In Alejandro Toledo \& Alain Chanlat (Eds.), Las otras caras de la sociedad informal: Una visión multidisciplinaria (pp. 37-70). Lima, Peru: ESAN/IDE.

Tuesta Soldevilla, Fernando. (2001). Perú político en cifras, 1821-2001 [Political Peru in numbers: 1821-2001] (3rd ed.). Lima, Peru: Fundación Friedrich Ebert.

Tuesta Soldevilla, Fernando. (1995). Sistema de partidos políticos en el Perú, 1978-1995 [Political party system in Peru, 1978-1995]. Lima, Peru: Fundación Friedrich Ebert.

Wilson, Tamar Diana. (1998). Introduction: The urban informal sector. Latin American Perspectives, 25(2), 3-17. 
Wright, Stephen G., \& Riker, William H. (1989). Plurality and runoff systems and numbers of candidates. Public Choice, 60(2), 155-175.

Yamada, Gustavo. (1996). Urban informal employment and self-employment in developing countries: Theory and evidence. Economic Development and Cultural Change, 44(2), 289314.

Charles D. Kenney received his Ph.D. from the University of Notre Dame in 1998 and is an assistant professor of comparative and Latin American politics at the University of Oklahoma. His primary areas of interest include democratization, constitutional design, electoral and party systems, and Peruvian politics. He lived in Peru from 1978-1979 and 1984-1991, was a Fulbright Fellow in Peru in 2000, and is the past chair of the Peru Section of the Latin American Studies Association. He was a member of the Latin American Studies Association delegation of international electoral observers for the 2000 Peruvian elections and the National Democratic Institute and Carter Center joint international observation mission in 2001. 